\title{
A Friendly Environment Approach for determination of paracetamol
}

\author{
Hana Sh. Mahmood \\ Department of Chemistry, College of Science, University of Mosul, Mosul, Iraq \\ Email: hnsheker@yahoo.com
}

(Received August 08, 2019; Accepted November 11, 2019; Available online June 01, 2020)

DOI: 10.33899/edusj.2019.125964.1011, @ 2020, College of Education for Pure Science, University of Mosul.

This is an open access article under the CC BY 4.0 license (http://creativecommons.org/licenses/by/4.0/).

\begin{abstract}
This paper involves a determination of paracetamol using less environment harmful reagent; the hydroxy analog of the pharmaceutical naproxen replaces the chemical reagent in which it is used as a coupling agent for the diazotized p-aminophenol (the hydrolysis product of paracetamol).The paper offers a determination of an analgesic paracetamol in the presence of high content of another analgesic.

Paracetamol azo-dye formed shows the higher absorption peak at $500 \mathrm{~nm}$. Absorbanceconcentration relation is liner over the range from 10 to $650 \mu \mathrm{g} / 20 \mathrm{ml}$, (i.e. 0.5-32.5 ppm) with a good sensitivity (molar absorptivity $1.2 \times 10^{4} 1 . \mathrm{mol}^{-1} \cdot \mathrm{cm}^{-1}$ ) ; good precision (RSD better than $\pm 0.275 \%$ ) and high accuracy (relative error less than $+0.77 \%$ ), Sandell's sensitivity index is $0.0124 \mu \mathrm{g} . \mathrm{cm}^{-2}$, the calculated limit of detection (LOD) is $0.0030 \mu \mathrm{g} / \mathrm{ml}$ and the evaluated limit of quantitation (LOQ) is $0.0101 \mu \mathrm{g} / \mathrm{ml}$. The application of the method exhibits a successful results for determination of paracetamol in dosage forms and it's already applied for the determination of paracetamol in presence of naproxen.
\end{abstract}

Key words: paracetamol, naproxene , spectrophotomety, friendly environment.

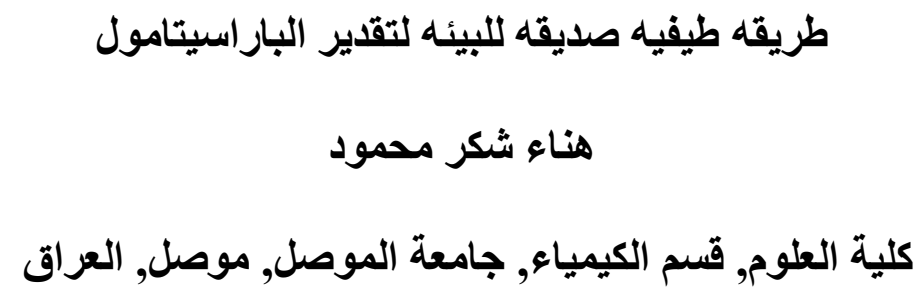

الخلاصه

يتضمن هذا البحث تقدير الباراسيتامول باستخدام كاشف أكثر امنا للبيئة اذ تم احلال النابروكسين المحور الى مناظره هيدروكسي نابروكسين (مركب دوائي) محل الكواشف الكيميائيه من خلال استخدامه كعامل اقتران للأمينوفينول (ناتج التحلل المائي للباراسيتامول) المؤزوت ، يقدم البحث تقديرا للباراسيتامول الدواء المسكن في وجود محتوى عالي من مسكن آخر الخر (النابروكسين). 


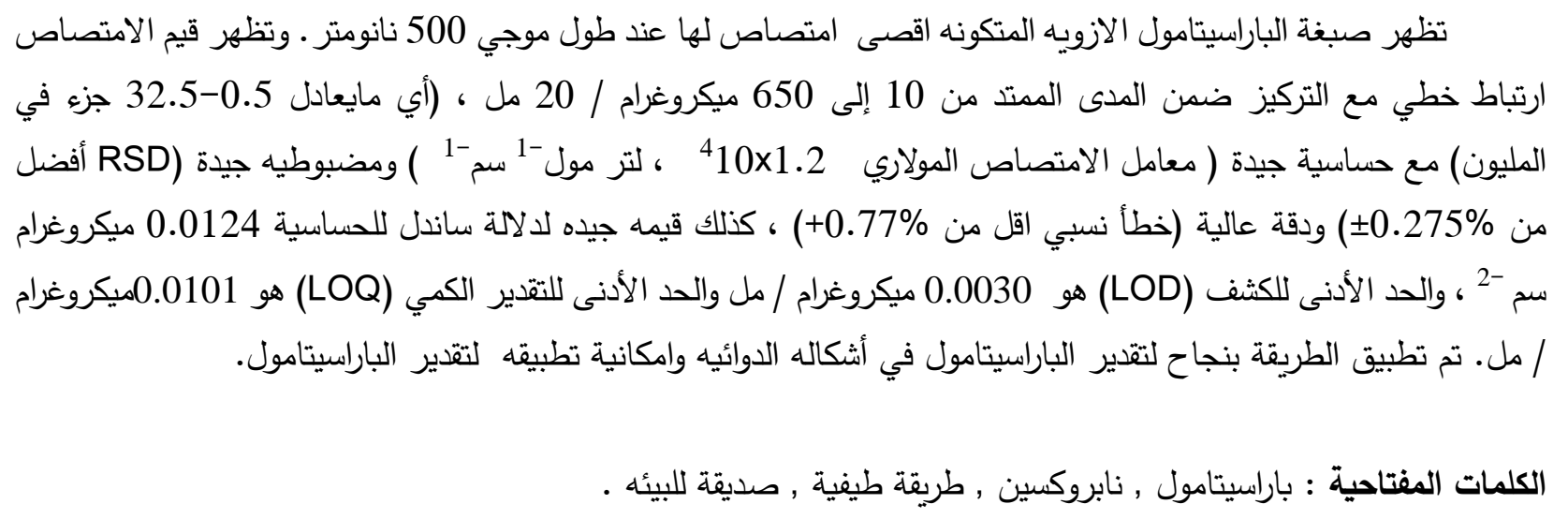

\section{Introduction}

Nowadays, the most important development concept in analytical chemistry is the modified version of an environmentally friendly approach [1], some of these concepts are the selection of the safer compounds [2].

A green, and economic method for determination of paracetamol in pharmaceutical preparations established, the method uv spectrophotomtry, which based on dissolving of sample in water, estimating the quantity of paracetamol at two wavelengths, then replacing the concentration in the equation of multi component system[3].

There were other procedures that can be classified under friendly environment these are phenylephrine via oxidative coupling [4], sulphacetamide as a diazotized agent coupled to paracetamol [5] and anthranilic acid as a coupling agent for diazotized paracetamol which is form a colored azo dye measured at $421 \mathrm{~nm}$.[6]

The same principle for determination of paracetamol but with more harmful reagents has been reported .The hemolysis compound [7] nitroaniline used for determination of paracetamol [8] , the irritant [9] thymol was used as a coupling agent for determination of paracetamol in alkaline medium to produce a colored product measured at 600nm.[10] and irritant [11] hexacyanoferrate was used for determination of paracetamol as an oxidant in the presence of ammonia followed by coupling reaction with phenol to form a colored product measured at $630 \mathrm{~nm} .[12]$, in addition to that the skin inflammatory compound [13] phloroacetophenone was used as a coupling compound to determine the diazotized p-aminophenol (hydrolyzed paracetamol) in basic medium [14]. Dichlorodicyano benzoquinone which produces the toxic $\mathrm{CN}$ in water [15] was used for determination of paracetamol via charge transfer reaction [16].

The aim of this work is the determination of a diazotized p-aminophenol (hydrolyzed paracetamol) using modified naproxen (mNap) as a safer compound than chemical reagents.

\section{Experimental}

\section{Apparatus}

All spectral and absorbance measurement were carried out on double-beam Jasco V-630 spectrophotometer with $1.0 \mathrm{~cm}$ matched quartz cells. $\mathrm{pH}$ measurements were performed using HANNA $301 \mathrm{pH}$ meter, BEL balance was used for weight measurements, reflux was utilized by electrothermal heater and stirring was utilized by Wisd stirrer.

\section{The chemicals}


All chemical reagents used were of an analytical grade

- Hydrolyzed paracetamol solution (HPAR) $(\mathbf{1 0 0} \mu \mathrm{g} / \mathrm{ml})$ : A10 $\mathrm{ml}$ ethanol was used to dissolve accurately weighed quantity of powder $0.025 \mathrm{~g}$ PAR (SDI), then 100-150 ml distilled water was added, (shaking was used to increase the solubility), filtered in to $250.0 \mathrm{ml}$ in volumetric flask, and the procedure for hydrolysis of paracetamol had been followed [17].

-Paracetamol solution $(\mathbf{1 0 0 0} \boldsymbol{\mu g} / \mathbf{m l}): 0.25 \mathrm{~g}$ of paracetamol was dissolved in $10 \mathrm{ml}$ ethanol then the solution was completed to $250.0 \mathrm{ml}$ in a volumetric flask with distilled water.

-Modified Naproxen ( hydroxy naproxen) synthesized and identified in previous research[18] was used in this article, Modified Naproxen (mNap) $\left(8 \times \mathbf{1 0}^{-4} \mathbf{M}\right): 0.0184 \mathrm{~g}$ of mNap (SDI) was dissolved in $2 \mathrm{ml}$ ethanol and the volume was completed to $100 \mathrm{ml}$ with distilled water in a volumetric flask. The solution was kept in dark bottle and is stay stable for at least one month.

-Sodium Nitrite $\left(\mathrm{NaNO}_{2}\right) \mathbf{1 \%}$ :, to prepare the solution, $1.0 \mathrm{~g}$ of pure sodium nitrite was dissolved in distilled water and the volume was completed to $100 \mathrm{ml}$ in a volumetric flask.

- Sodium hydroxide solution (1M): to prepare this solution an appropriate dilution of the concentrated solution (Fluka) was diluted with distilled water to $1000 \mathrm{ml}$ in a volumetric flask and then transferred to a plastic bottle.

- Paracetamol Tablet solution (1000 $\left.\boldsymbol{\mu g} \cdot \mathbf{m l}^{-\mathbf{1}}\right)$ : 10 tablets (each one contains $500 \mathrm{mg}$ PAR) was weighted and finely powdered. Quantity of powder exactly equivalent to $0.25 \mathrm{~g}$ PAR was dissolved in $10.0 \mathrm{ml}$ ethanol, a dilution by $100-150 \mathrm{ml}$ distilled water was done then it was filtered and completed to $250.0 \mathrm{ml}$ in volumetric flask, similar procedure for hydrolysis of paracetamol had been followed.

- Paracetamol injection solution $\left(\mathbf{1 0 0 0} \boldsymbol{\mu g} \cdot \mathrm{ml}^{-\mathbf{1}}\right)$ : The contain of 3 injections were mixed , a 2.5 $\mathrm{ml}$ equivalent to $250 \mathrm{mg}$ paracetamol was diluted to $250.0 \mathrm{ml}$ with distilled water in a volumetric flask, $150.0 \mathrm{ml}$ of the last solution was prepared by following the preparation of HPAR in Tablet.

- Paracetamol syrup solution(1000 $\boldsymbol{\mu g} / \mathbf{m l})$ :A $10.41 \mathrm{ml}$ of antipyrol syrup (each $5 \mathrm{ml}$ contain 120 mg PAR ) was diluted to $250 \mathrm{ml}$ with distilled water in a volumetric flask; $150 \mathrm{ml}$ of the last solution was prepared by following the preparation of HPAR in Tablet.

\section{Procedure and calibration graph:}

To increasing volume $(0.1-6.5) \mathrm{ml}$ of $100 \mu \mathrm{g} \cdot \mathrm{ml}^{-1}$ standard paracetamol solution, the following reagents has been added in the following orders : $1.0 \mathrm{ml}$ of $\mathrm{H}_{3} \mathrm{PO}_{4}(1 \mathrm{M}), 1.0 \mathrm{ml}$ of $1 \% \mathrm{NaNO}_{2}, 0.5$ $\mathrm{ml}$ of $3 \%$ sulphamic acid, $3 \mathrm{ml}$ of $\left(8 \times 10^{-4} \mathrm{M}\right) \mathrm{mNap}$ and $2 \mathrm{ml}$ of $\mathrm{NaOH}(1 \mathrm{M})$ has been finally added , then they were diluted to $20 \mathrm{~mL}$, The absorbance has been measured at $500 \mathrm{~nm}$ against blank.

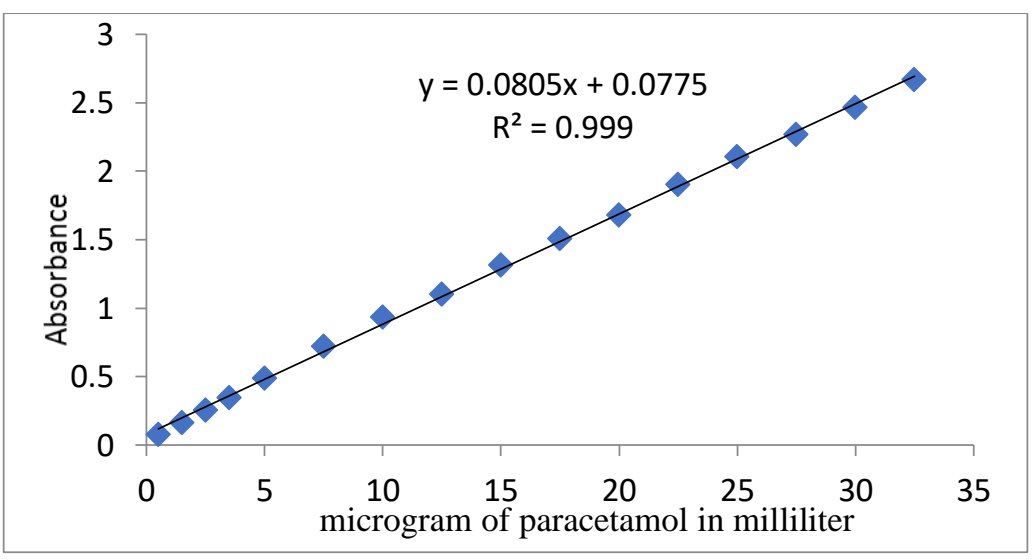

Figure 1 - Calibration Graph for Estimation of Paracetamol 
The relation between absorbance and concentration shows a good linearity over the range of the concentration between 10 to $650 \mu \mathrm{g}$ of Paracetamol in $20 \mathrm{ml}(0.5-32.5 \mathrm{ppm})$ with good sensitivity in which that the molar absorptivity is $1.2 \times 10^{4} 1 . \mathrm{mol}^{-1} \cdot \mathrm{cm}^{-1}$ and sensitivity index of Sandell is $0.0124 \mu \mathrm{g} / \mathrm{cm}^{2}$.

\section{The study of the optimum reaction conditions}

The selection of acid and its quantity

The effect of different quantities (0.5-2.5 ml) of many acids (hydrochloric, sulphuric, nitric, phosphoric, and acetic acid) (1M) on absorption intensity has been studied Table (1) shows the results.

Table (1): Selection of Acid and its Quantity

\begin{tabular}{||l|l|l|l|l|l|}
\hline \multirow{2}{*}{$\begin{array}{l}\text { Acid used } \\
(\mathbf{1 M})\end{array}$} & \multicolumn{5}{|l|}{ Absorbance/ $\mathbf{m l}$ of acid } \\
\cline { 2 - 6 } & $\mathbf{0 . 5}$ & $\mathbf{1 . 0}$ & $\mathbf{1 . 5}$ & $\mathbf{2 . 0}$ & $\mathbf{2 . 5}$ \\
\hline $\mathbf{H C l}$ & 0.175 & 0.200 & 0.244 & 0.380 & 0.115 \\
\hline $\mathbf{H}_{\mathbf{2}} \mathbf{S O}_{4}$ & 0.148 & 0.178 & 0.235 & 0.093 & 0.055 \\
\hline $\mathbf{H N O}_{3}$ & 0.151 & 0.162 & 0.176 & 0.193 & 0.206 \\
\hline $\mathbf{H}_{\mathbf{3}} \mathbf{P O}_{4}$ & 0.254 & $\mathbf{0 . 4 5 5}$ & 0.447 & 0.097 & 0.064 \\
\hline $\mathbf{C H}_{\mathbf{3}} \mathbf{C O O H}$ & 0.213 & 0.234 & 0.257 & 0.453 & 0.121 \\
\hline
\end{tabular}

Table (1) makes it clear that, the maximum absorptions intensity of the colored product results when $1.0 \mathrm{ml}$ of $\mathrm{H}_{3} \mathrm{PO}_{4}$ was used to justify the reaction medium.

Effect of nitrite quantity with time

Between $0.1 \mathrm{ml}$ to $1.2 \mathrm{ml}$ of $\mathrm{NaNO}_{2}(1 \%)$ has been checked with a standing time from 0 to 5 min, Table (2).

Table (2): The Effect of Nitrite Quantity With Time

\begin{tabular}{|c|c|c|c|c|c||}
\hline \multirow{2}{*}{$\begin{array}{c}\text { ml of (1\%) NaNO } \\
\text { solution }\end{array}$} & \multicolumn{5}{|c|}{ Absorbance / minute standing time } \\
\cline { 2 - 6 } & $\mathbf{1}$ & $\mathbf{2}$ & $\mathbf{3}$ & $\mathbf{4}$ & $\mathbf{5}$ \\
\hline $\mathbf{0 . 1}$ & 0.448 & 0.443 & 0.448 & 0.447 & 0.431 \\
\hline $\mathbf{0 . 3}$ & 0.445 & 0.448 & 0.446 & 0.445 & 0.447 \\
\hline $\mathbf{0 . 5}$ & 0.452 & 0.454 & 0.456 & 0.458 & 0.459 \\
\hline $\mathbf{0 . 7}$ & 0.476 & 0.484 & 0.489 & 0.488 & 0.474 \\
\hline $\mathbf{1 . 0}$ & 0.472 & $\mathbf{0 . 4 9 3}$ & 0.488 & 0.489 & 0.473 \\
\hline $\mathbf{1 . 2}$ & 0.478 & 0.487 & 0.491 & 0.489 & 0.481 \\
\hline
\end{tabular}

Table (2) exhibits that the reaction needs two minutes to reach optimum and $1.0 \mathrm{ml}$ of $1 \% \mathrm{NaNO}_{2}$ is the best quantity required for the completion.

\section{Effect of sulphamic acid quantity with time}

Between 0.3-1.5 $\mathrm{ml}$ of $3 \%$ of sulphamic acid was used, and absorbance of the solutions was measured at different standing time. 
Table (3):Effect of Sulphamic Acid Quantity With Time

\begin{tabular}{|c|c|c|c|c|c|}
\hline \multirow{2}{*}{$\begin{array}{c}\text { ml of sulphamic } \\
\text { acid (3\% ) } \\
\text { solution }\end{array}$} & \multicolumn{5}{|c|}{ Absorbance/minute standing time with shaking } \\
\cline { 2 - 6 } & $\mathbf{1}$ & $\mathbf{2}$ & $\mathbf{3}$ & $\mathbf{5}$ & $\mathbf{7}$ \\
\hline $\mathbf{0 . 3}$ & 0.044 & 0.040 & 0.068 & 0.053 & 0.051 \\
\hline $\mathbf{0 . 5}$ & 0.443 & 0.452 & 0.456 & $\mathbf{0 . 4 8 9}$ & 0.480 \\
\hline $\mathbf{0 . 7}$ & 0.445 & 0.452 & 0.452 & 0.485 & 0.483 \\
\hline $\mathbf{1 . 0}$ & 0.441 & 0.447 & 0.458 & 0.486 & 0.483 \\
\hline $\mathbf{1 . 2}$ & 0.444 & 0.438 & 0.456 & 0.480 & 0.477 \\
\hline $\mathbf{1 . 5}$ & 0.446 & 0.438 & 0.459 & 0.472 & 0.478 \\
\hline
\end{tabular}

Table (3) indicate that five minutes as a standing time was preferred and $0.5 \mathrm{ml}$ of $3 \%$ of sulphamic acid was selected .

\section{The Effect of coupling agent quantity}

The effect of $(1-5) \mathrm{ml}$ of $\left(8 \times 10^{-4} \mathrm{M}\right)$ coupling agent has been studied against $10-150 \mu \mathrm{g}$ of Paracetamol/20 $\mathrm{ml}$; the determination coefficient of a measured absorbance has been evaluated. Table (4) shows that $3 \mathrm{ml}$ and $4 \mathrm{ml}$ of coupling agent solution gives the higher determination coefficient but $3 \mathrm{ml}$ exhibits the best sensitivity.

Table (4): The Effect of Coupling Agent Quantity

\begin{tabular}{|c|c|c|c|c|c|c|c|c|c|}
\hline \multirow{2}{*}{$\begin{array}{c}\text { ml of } \\
\text { mNap } \\
\left(8 \times 10^{-4} \mathrm{M}\right) \\
\end{array}$} & \multicolumn{8}{|c|}{ Absorbance, $\mu \mathrm{g} / 20 \mathrm{ml}$ of Para } & \multirow{2}{*}{$\mathbf{R}^{2}$} \\
\hline & 10 & 30 & 50 & 70 & 100 & 150 & 200 & 250 & \\
\hline 1 & 0.044 & 0.129 & 0.213 & 0.299 & 0.444 & 0.685 & 0.866 & 1.116 & 0.9990 \\
\hline 2 & 0.075 & 0.148 & 0.234 & 0.339 & 0.460 & 0.701 & 0.900 & 1.128 & 0.9994 \\
\hline 3 & 0.076 & 0.162 & 0.254 & 0.348 & 0.488 & 0.721 & 0.944 & 1.169 & 0.9999 \\
\hline 4 & 0.075 & 0.157 & 0.243 & 0.338 & 0.467 & 0.687 & 0.907 & 1.115 & 0.9999 \\
\hline 5 & 0.075 & 0.148 & 0.240 & 0.325 & 0.462 & 0.687 & 0.897 & 1.102 & 0.9997 \\
\hline
\end{tabular}

Selection of base and its quantity

A higher conjugation and a bigger chromophor area are the results of removing the acidic hydrogen from conjugated product; for this reason, four types of bases or basic salts at different volumes (1-5) $\mathrm{ml}$ of each have been tested. See Table (5). 
Table (5): The Selection of Base and its Quantity

\begin{tabular}{||c|c|c|c|c|c||}
\hline \multirow{2}{*}{$\begin{array}{c}\text { Base used } \\
(\mathbf{1 M})\end{array}$} & \multicolumn{5}{|c|}{ ml of base used } \\
\cline { 2 - 6 } & $\mathbf{1}$ & $\mathbf{2}$ & $\mathbf{3}$ & $\mathbf{4}$ & $\mathbf{5}$ \\
\hline $\mathbf{N a O H}$ & 0.049 & $\mathbf{0 . 4 8 9}$ & 0.446 & 0.432 & 0.211 \\
\hline $\mathbf{K O H}$ & 0.415 & 0.451 & 0.460 & 0.461 & 0.458 \\
\hline $\mathbf{N a}_{2} \mathbf{C O}_{3}$ & 0.042 & 0.434 & 0.443 & 0.457 & 0.450 \\
\hline $\mathbf{N a H C O} 3$ & 0.070 & 0.455 & 0.301 & 0.213 & 0.179 \\
\hline
\end{tabular}

Table (5) shows that $2 \mathrm{ml}$ of sodium hydroxide $(1 \mathrm{M})$ is the best one and it was used from the beginning.

\section{The Effect of surfactant}

In order to study the effect of surfactants on absorption intensity, $2 \mathrm{ml}$ of SDS, CPC, and CTAB surfactants with different orders of additions were followed as its shown in Table (6).

Table (6): Effect of Surfactants

\begin{tabular}{|c|c|c|c|c|c|c|}
\hline \multirow{2}{*}{$\begin{array}{l}\text { Surfactant solution } \\
\qquad\left(1 \times 10^{-3} \mathbf{M}\right)\end{array}$} & \multicolumn{6}{|c|}{ Absorbance/order* of addition } \\
\hline & $\mathbf{I}$ & II & III & IV & $\mathbf{V}$ & VI \\
\hline SDS & 0.486 & 0.487 & 0.487 & 0.488 & 0.480 & 0.477 \\
\hline CTAB & 0.342 & 0.349 & 0.354 & 0.354 & 0.351 & 0.348 \\
\hline CPC & 0.347 & 0.354 & 0.350 & 0.343 & 0.342 & 0.339 \\
\hline
\end{tabular}

* I. paracetamol (Para) + surfactant $(\mathrm{S})+\mathrm{H}_{3} \mathrm{PO}_{4}(\mathrm{H})+\mathrm{NaNO}_{2}(\mathrm{~N})+$ Sulphamic acid $(\mathrm{F})$ + mNaproxen $(\mathrm{D})+\mathrm{NaOH}(\mathrm{B})$

II. $\mathrm{Para}+\mathrm{H}+\mathrm{S}+\mathrm{N}+\mathrm{F}+\mathrm{D}+\mathrm{B}$

III. $P$ ara $+\mathrm{H}+\mathrm{N}+\mathrm{S}+\mathrm{F}+\mathrm{D}+\mathrm{B}$

IV. Para $+\mathrm{H}+\mathrm{N}+\mathrm{F}+\mathrm{S}+\mathrm{D}+\mathrm{B}$

V. $\quad$ Para $+\mathrm{H}+\mathrm{N}+\mathrm{F}+\mathrm{D}+\mathrm{S}+\mathrm{B}$

VI. Para $+\mathrm{H}+\mathrm{N}+\mathrm{F}+\mathrm{D}+\mathrm{B}+\mathrm{S}$

\section{The Stability of reaction}

The stability of the colored product against time has been followed using three different concentrations of Paracetamol, Table (7) indicates that the colored product keeps stable for at least 60 minutes. 
Table (7): The Stability of the Colored Product

\begin{tabular}{|c|c|c|c|}
\hline \multirow{2}{*}{ Time, minute } & \multicolumn{3}{|c|}{ Absorbance/ $\boldsymbol{\mu g}$ of Para present in 20ml } \\
\cline { 2 - 4 } & $\mathbf{5 0}$ & $\mathbf{1 0 0}$ & $\mathbf{2 0 0}$ \\
\hline $\mathbf{2}$ & 0.252 & 0.486 & 0.944 \\
\hline $\mathbf{5}$ & 0.252 & 0.486 & 0.944 \\
\hline $\mathbf{1 0}$ & 0.252 & 0.484 & 0.944 \\
\hline $\mathbf{1 5}$ & 0.254 & 0.484 & 0.944 \\
\hline $\mathbf{2 0}$ & 0.254 & 0.484 & 0.944 \\
\hline $\mathbf{2 5}$ & 0.254 & 0.484 & 0.944 \\
\hline $\mathbf{3 0}$ & 0.254 & 0.484 & 0.944 \\
\hline $\mathbf{3 5}$ & 0.254 & 0.484 & 0.944 \\
\hline $\mathbf{4 0}$ & 0.254 & 0.484 & 0.944 \\
\hline $\mathbf{4 5}$ & 0.254 & 0.484 & 0.944 \\
\hline $\mathbf{5 0}$ & 0.254 & 0.484 & 0.944 \\
\hline $\mathbf{5 5}$ & 0.254 & 0.484 & 0.944 \\
\hline $\mathbf{6 0}$ & 0.254 & 0.484 & 0.944 \\
\hline $\mathbf{9 0}$ & 0.254 & 0.484 & 0.944 \\
\hline $\mathbf{1 2 0}$ & 0.254 & 0.484 & 0.944 \\
\hline $\mathbf{1 8 0}$ & 0.254 & 0.484 & 0.944 \\
\hline $\mathbf{1 ~ d a y}$ & 0.254 & 0.484 & 0.944 \\
\hline
\end{tabular}

Absorption Spectra

Under the optimum reaction conditions, the absorption spectrum of the colored product against blank (Fig.2) shows that wavelength of maximum absorption intensity is $500 \mathrm{~nm}$.this wavelength has been used in subsequent investigations.

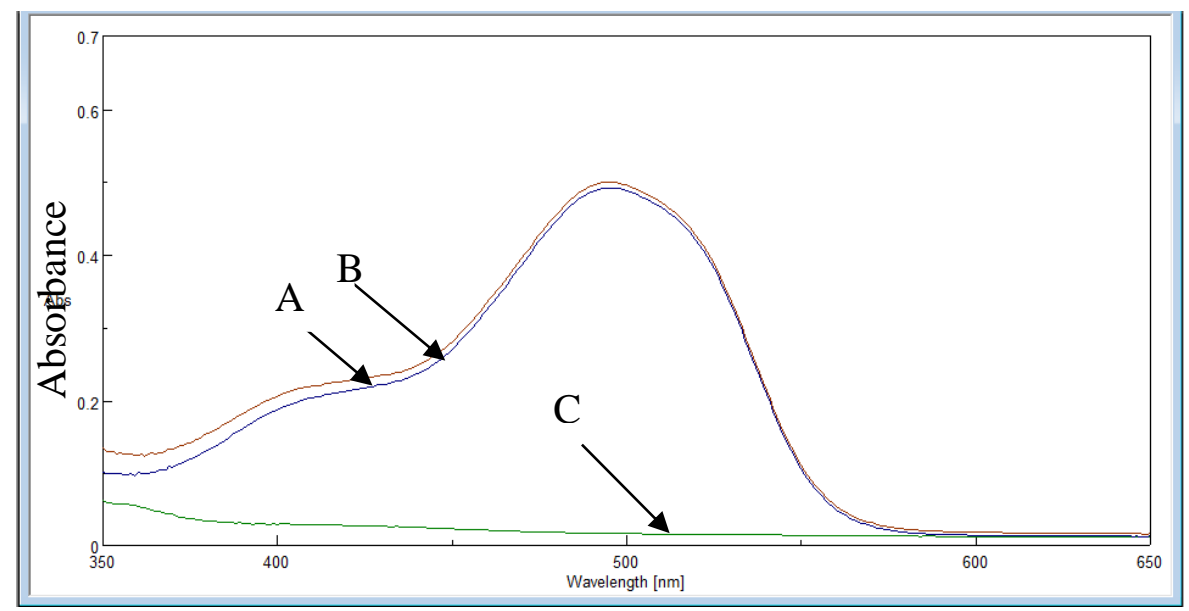

A: Sample Against Blank

Figure (2): Absorption Spectrum

B: Sample Against Distilled Water

C: Blank Against Distilled Water 


\section{Accuracy and Precision}

Paracetamol is determined at three different concentrations for checking the accuracy and precision, Table (8) indicates that the reaction is accurate (the relative error from -2.11 to 0.77 ) and precise (the relative standard deviation is from \pm 0.068 to \pm 0.275 ).

Table (8): Accuracy and Precision

\begin{tabular}{|c|c|c|}
\hline $\begin{array}{c}\text { Quantity Para taken } \\
\boldsymbol{\mu g} / \mathbf{2 0} \mathbf{~ m l}\end{array}$ & Relative Error \%* & $\begin{array}{c}\text { Relative Standard } \\
\text { Deviation \%* }\end{array}$ \\
\hline $\mathbf{5 0}$ & 0.77 & \pm 0.275 \\
\hline $\mathbf{1 0 0}$ & -0.62 & \pm 0.146 \\
\hline $\mathbf{1 5 0}$ & -2.11 & \pm 0.068 \\
\hline
\end{tabular}

*Average of five determination

\section{Effect of organic solvents}

The characteristic of the colored product is more detectable using acetic acid and water than that using other solvents which they were turbid or completely separated into two layers. Water is still being a choice.

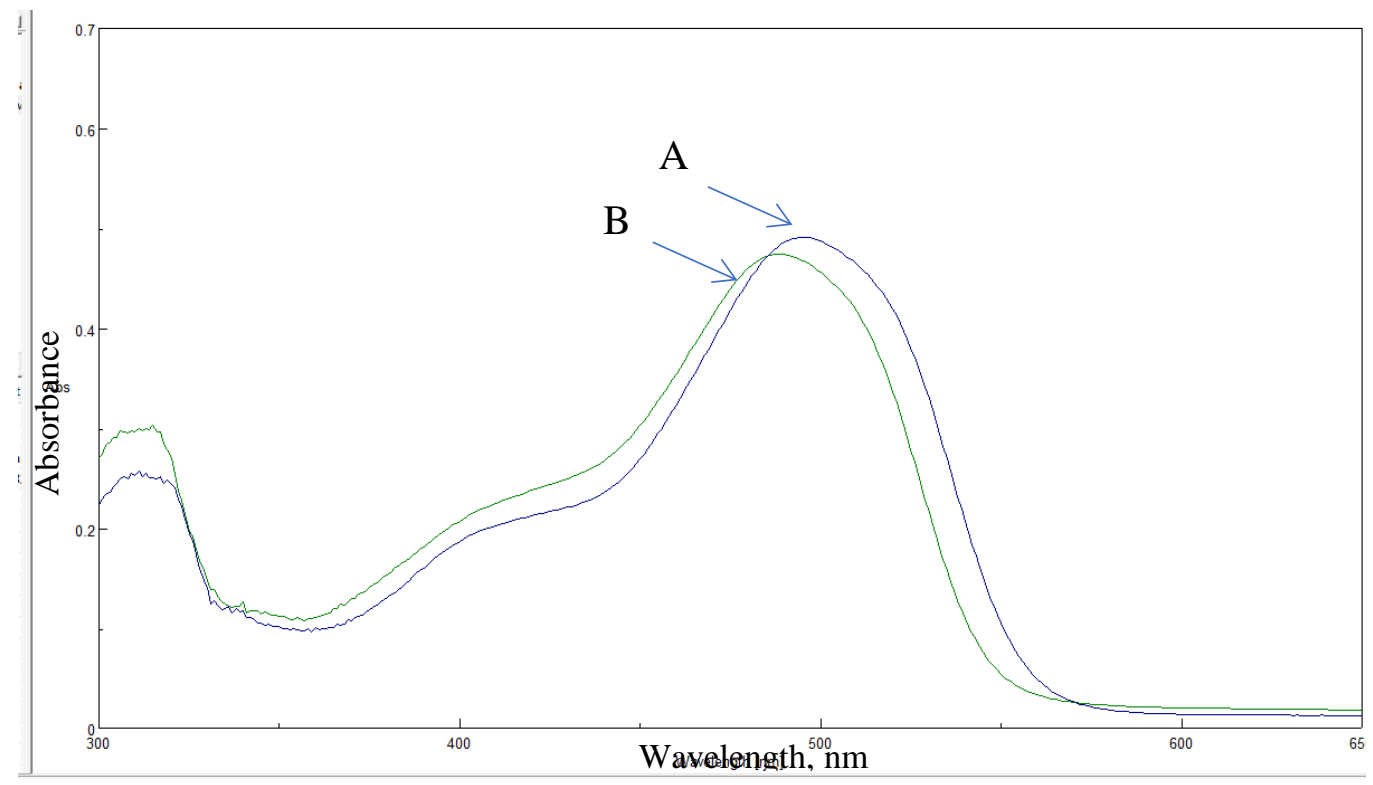

\section{Figure (3): Effect of Organic Solvents}

\section{Effect of foreign compounds}

\section{A: Acetic acid B: Water}

to realize the application of this method, the interferences of foreign compounds have been studied by following the recommended procedure of $100 \mu \mathrm{g}$ of paracetamol in the presence of 100 , $300,500,1000 \mu \mathrm{g}$ of expected foreign compounds using the recommended procedure. Table (9). 
Table (9): Effect of Interferences

\begin{tabular}{|l|l|l|l|l|}
\hline \multirow{2}{*}{ Interferences } & \multicolumn{4}{|c|}{ Recovery / $\mathbf{4 g}$ of Interferences } \\
\cline { 2 - 5 } & 100 & 300 & 500 & 1000 \\
\hline Starch & 100.0 & 101.6 & 102.7 & 103.2 \\
\hline Glucose & 99.2 & 102.2 & 101.2 & 100.3 \\
\hline Gum Arabic & 97.1 & 100.2 & 101.0 & 100.4 \\
\hline Lactose & 98.9 & 97.2 & 99.45 & 102.1 \\
\hline
\end{tabular}

Table (10) indicates that there was no interfering effect caused by the studied foreign compounds at different fold excess of these compounds.

\section{Application of the method}

The method has been applied to the determination of paracetamol in the dosage forms. The results are listed in Table (10) indicating a good applicability of the method.

Table (10): Application of the Method

\begin{tabular}{|c|c|c|c|c|}
\hline \multirow{2}{*}{$\begin{array}{c}\text { Quantity of } \\
\text { HPAR /20 ml }\end{array}$} & $\begin{array}{c}\text { Paracetamol } \\
\text { Tablet (500 } \\
\text { mg)-SDI }\end{array}$ & $\begin{array}{c}\text { Panda Tablet } \\
(1000 \mathrm{mg})- \\
\text { Paracetamol- } \\
\text { Joswe }\end{array}$ & $\begin{array}{c}\text { Paracetamol } \\
\text { Syrup } \\
120 \text { mg in 5 ml- } \\
\text { S.D.I }\end{array}$ & $\begin{array}{c}\text { Paracetamol } \\
\text { injection }(500 \mathrm{mg} / \\
5 \mathrm{ml})-\end{array}$ \\
$\begin{array}{c}\text { Pharmaceutical } \\
\text { /India }\end{array}$ \\
\hline 50 & 98.3 & 100.1 & 100.0 & 99.9 \\
\hline 100 & 98.7 & 99.8 & 97.9 & 99.8 \\
\hline 150 & 99.2 & 100.0 & 98.2 & 99.9 \\
\hline
\end{tabular}

*Average of three determinations

\section{Evaluation of analytical data}

T- test has been used for evaluation of the method statistically ; The present method and British Pharmacopeia one [19] have been applied at the same time for t-test calculation [20] ; the value compared with statistical Tables for four degrees of freedom at $95 \%$ validation level; Table (11) shows that there is an identical ability to application. 
Table (11): Application of Method on Drug Formulation and Evaluation of T-Test

\begin{tabular}{|c|c|c|c|}
\hline \multirow{2}{*}{ Drug } & \multicolumn{2}{|c|}{ Recovery*\% } & \multirow{2}{*}{ t-exp } \\
\cline { 2 - 3 } & $\begin{array}{c}\text { Present } \\
\text { method }\end{array}$ & $\begin{array}{c}\text { British Pharmacopeia } \\
\text { method }\end{array}$ & $0.35+$ \\
\hline $\begin{array}{c}\text { Paracetamol Tablet } \\
\text { (500 mg) -S.D.I }\end{array}$ & 101.0 & 99.6 & -0.21 \\
\hline $\begin{array}{c}\text { Panda Tablet (1000 } \\
\text { mg)-Paracetamol- } \\
\text { Joswe }\end{array}$ & 99.5 & 100 & +1.45 \\
\hline $\begin{array}{c}\text { Paracetamol Syrup } \\
120 \text { mg in 5 ml- S.D.I }\end{array}$ & 99.7 & 99.8 & +1.67 \\
\hline $\begin{array}{c}\text { Paracetamol injection } \\
\text { (500 mg/ 5 ml)- } \\
\text { Pharmaceutical /India }\end{array}$ & 99.3 & 99.9 & \\
\hline
\end{tabular}

* Average of three determinations

\section{Conclusion}

A Friendly environment precise with good sensitivity method has been used for the determination of paracetamol in their pharmaceutical preparations (tablet, syrup, and injection) excluding the toxic reagents, don't need organic solvent; and don't need separation steps or adjustment of $\mathrm{pH}$.

\section{References}

1. Migueld, D., and Salvador, G., "Handbook of Green Analytical Chemistry",1 st. Edn., John Wiley and Sons, Inc., New York,CD (2012).

2. Ana M., Maria E, jose L., and Bernado M., green chemistry letters and reviews , 7 (1) 5059. (2014).

3. Hana Sh. and Nagham T .,Rad. J . sci .,27 (1), 36-42. (2018).

4. Muhsen F.and Raeed M., J. Duhok univ.14 (1), 53-56. (2011).

5. Gessso S.G, development of spectrophotometric method for the determination of some organic compound in pharmaceutical preparation, M. Sc. Thesis, university of Mosul (1991).

6. Mohmmed S. , Raheem K. , Al samarria S. Ibn Al-haitham J. Pur. Appl.Sci. , 29 ( 2 ), 409420. (2017)

7. Vernot E.H. .Mac Ewen C.Haun C.Kinkead E.R., Toxi.Appl.Pharm.42 (2), 417-423. (1977).

8. Belal S. ,Elsayed M. ,El-waliely A. and Abdine, J.pharm.sci.,68(6),750-753. (1979).

9. The Merck Manual ,17 ${ }^{\text {th }}$ Edn., Merck and Co., Inc., illustrated on CD-ROM (1999).

10. Frha Kh., Iraq.Nati.j.chem. 53,36-42. (2014).

11. Lawrence K. Wang, Yung-Tse Hung, Howard H. $2^{\text {nd }}$.Edn., Hand book of Industrial and hazardous wastes treatment, Marcel dekkar, Inc., New York, net. (2006).

12. Koos J.,Van F., and Tsanwani M.,Talanta,58(6),1095-1101.(2002).

13. Pravin K, J. Appl. Toxi., (1994).

14. Nabeel S.,and Safaa J.Edu.Sci.,19(3),21-32. (2007). 
15. Prakash V., Organofiuorine compounds in biology and medicine, Elsevier B.V., USA, p.289. (2015).

16. Al-Enizzi M.,Development of spectrophotometric method for trace determination of paracetamol, histamine and some sulpha drugs, M.Sc.Thesis, University of Mosul. (2002).

17. Mohammad S.Y., Indirect spectrophotometric determination of paracetamol application to pharmaceutical preparations, M.Sc.Thesis, University of Mosul. (2018).

18 Al-Hamdany F.K., Synthesis of some (s)-2-(6'-methoxy-2'-naphthyl) propanoic acid derivatives (Naproxen), ph. D. Thesis, university of Mosul, pp 39,62. (2009).

19. British Pharmacopeia.. $7^{\text {th }}$ Edn., System Simulation Ltd the Stationary Office ,Londone....CD ROM. (2013).

20. Skoog D. A., West D. M., F. ," Fundamentals of Analytical Chemistry,",9th Edn., Mary Finch, Inc., Belmont, CA 94002-3098,USA, p127. (2014). 